\title{
Kajian Peningkatan Peran Azolla Sebagai Pupuk Organik Kaya Nitrogen pada Padi Sawah
}

\section{Study Increasing Role of Azolla As Nitrogen Rich Organic Fertilizer on Rice}

\section{Iwan Gunawan}

Jurusan Budidaya Tanaman Pangan Politeknik Negeri Lampung

Jl. Soekarno Hatta No. 10 Rajabasa Bandar Lampung. Tel. (0721)703995 Faks. 787309

\begin{abstract}
The study aims to get an optimum dose of Azolla organic fertilizer that provides maximum growth and yield of rice crops. The experiments are arranged in complettely randomized block design with 5 treatments and 4 replications. The treatments tested were fresh Azolla biomass dose embedded in the ground to accompany the provision of Azolla that left to grow on the surface of the water of the rice fields. Treatments dose of fresh Azolla biomass awere $\mathrm{M}_{0}=$ control (without organic fertilizer Azolla); $\mathrm{M}_{1}=100 \mathrm{~g} \cdot \mathrm{pot}^{-1} ; \mathrm{M}_{2}=200 \mathrm{~g}$. $\operatorname{pot}^{-1} ; \mathrm{M}_{3}=300$ g. pot $^{-1}$; and $\mathrm{M}_{4}=400 \mathrm{~g}$. $\operatorname{pot}^{-1}$. The experimental results show that: (1) organic fertilizer Azolla improve the growth and yield of rice paddy fields, and (2) Results of maximum 56.35 grams of dry grain per plant with an optimal dose of organic fertilizer as much as 48.102 ton.ha ${ }^{-1}$.
\end{abstract}

Keywords: Organic fertilizers, Fresh Azolla, growth, yield, rice paddy.

Diterima: 19-03-2014, disetujui: 02-05-2014

\section{PENDAHULUAN}

Di Indonesia padi menempati posisi sebagai tanaman pangan strategis. Sejalan dengan pertambahan penduduk, kebutuhan beras setiap tahunnya terus meningkat sehingga produksi padi harus ditingkatkan. Salah satu permasalahan yang kini dihadapi para petani adalah menurunya kesuburan lahan. Permasalahan ini secara umum disebabkan karena dipacunya lahan untuk berproduksi semaksimal mungkin secara terus menerus untuk mengejar peningkatan produktivitas (Rahmatika, 2010).

Tidak disadari hal tersebut berakibat pada pengurasan unsur hara dari dalam tanah secara tidak terkendali terutama unsur hara Nitrogen dan yang lebih kritis lagi adalah makin berkurangnnya bahan organik di dalam tanah. Untuk mengatasinya diperlukan masukan yang bukan hanya dapat menyediakan unsur hara terutama Nitrogen, namun sekaligus mampu memperkaya bahak organik tanah. Input ini berperan sebagai suplemen tambahan bahan pupuk anorganik yang biasa dipakai oleh para petani. 

Iwan Gunawan: Kajian Peningkatan Peran Azolla Sebagai Pupuk Organik Kaya Nitrogen...

Salah satu sumber bahan organik alternatif ini adalah Azolla. Biomassa azolla dapat dijadikan sebagai pupuk organik sumber Nitrogen $(\mathrm{N})$ yang cocok dikembangkan oleh para petani dan sangat mudah untuk diaplikasikan serta relatif murah karena tidak memerlukan biaya tambahan yang memberatkan petani.

Beberapa penelitian telah membuktikan antara lain bahwa lapisan Azolla di atas permukaan lahan sawah dapat menghemat penggunaan Urea sebesar $50 \mathrm{~kg} / \mathrm{ha}$, kadangkala bila musim sangat baik Azolla dapat menghemat sampai dengan $100 \mathrm{~kg}$ urea/ha (Kusumo, 2008 ). Kombinasi perlakuan yang terbaik adalah perlakuan penggunaan lapisan Azolla dan takaran pupuk Urea 60 kg N/ha (Hendrarti, E.; Sopandie, D.; Idris, K.;dan Sisworo, E.L., 1998). Pemakaian Azolla yang ditumbuhkan selama daur hidup padi dapat meningkatkan efisiensi penggunaan urea prill dibanding dengan yang dibenamkan sebelum tanam padi (Rasjid, H.; Sisworo, E.L.; Wemay, Y.; Sisworo, W.H., 2000). Dengan cara budidaya padi dengan Azolla, pemupukan dengan pupuk sintetis (urea) dapat dihemat 50\% (Haryanto, 2010).

Berasarkan informasi di atas tergambar adanya potensi untuk mengoptimalkan peranan azolla, tidak sekedar mensubstitusi sebagian keperluan pupuk urea, tetapi bagaimana apabila kebutuhan nitrogen tanaman padi sawah seluruhnya disuplai dari azolla. Berdasarkan penelitin sebelumnya diperoleh bahwa peningkatan berat kering gabah pada pemberian azolla tanpa Urea cenderung lebih baik daripada pemberian urea tanpa azolla (Gunawan, I. dan R. Kartina. 2012). Selanjutnya pemberian kompos azolla dengan dosis 6 t.ha ${ }^{-1}$ memberikan hasil terbaik tanaman padi sawah sebesar 12,05 t.ha ${ }^{-1}$ atau meningkatkan berat produksi gabah sebesar 21,03\% (Kaimuddin, Bachrul Ibrahim dan Lina Tangko. 2008; Anna Hedhiati. 2008). Untuk itu perlu dilakukan penelitian untuk mencari teknis budidaya yang dapat mengoptimalkan peranan azolla untuk menggantikan seluruh kebutuhan nitrogen tanaman padi sawah.

\section{METODE}

Penelitian dilaksanakan di Rumah Kaca Politeknik Negeri Lampung. Waktu penelitian adalah bulan September 2013 sampai dengan Desember 2013. Bahan yang digunakan dalam penelitian antara lain inokulum Azolla strain lokal Lampung, Ember plastik berdiameter $40 \mathrm{~cm}$, Benih padi varietas Ciherang, pupuk Urea, SP-36 dan KCl. Alat-alat yang digunakan dalam penelitian antara lain $\mathrm{pH}$ meter, EC meter, termometer, timbangan, kantung plastik, kantung kertas, dan oven.

Percobaan disusun dalam Rancangan Kelompok Teracak Lengkap (RKTL) dengan 5 perlakuan dan 4 ulangan. Perlakuan yang dicobakan adalah takaran biomasa azolla segar yang dibenamkan dalam tanah untuk menyertai pemberian azolla yang dibiarkan tumbuh di atas permukaan air sawah. Selengkapnya perlakuan takaran biomasa azolla segar tersebut adalah $\mathbf{M}_{0}=$ kontrol (tanpa pupuk organik azolla); $\mathrm{M}_{1}=$ Azolla $100 \mathrm{~g} \cdot \operatorname{pot}^{-1} ; \mathrm{M}_{2}=$ Azolla $200 \mathrm{~g} \cdot \operatorname{pot}^{-1} ; \mathrm{M}_{3}=$ Azolla 300g. pot $^{-1}$ dan $\mathrm{M}_{4}=$ Azolla 400g. pot $^{-1}$

Satuan percobaan berupa pot plastik berdiameter $40 \mathrm{~cm}$, sehingga terdapat 20 pot plastik satuan percobaan. Masing-masing parameter data uji dengan Analisis Ragam, dan apabila hasil analisis terdapat perlakuan yang menunjukkan pengaruh yang berbeda nyata maka akan dilanjutkan dengan uji perbedaan nilai tengah rata-rata menggunakan Uji BNT pada taraf 5\%. Untuk mendapatkan nilai optimal dosis pupuk organik azolla akan dilakukan dengan Analisis Regresi dan Permukaan Respons (Responds Surface Analysis). 
Sebelum digunakan, inokulum tumbuhan air azolla diperbanyak pada kolam perbanyakan yang dibuat lembaran plastik berukuran $2 \mathrm{~m}$ x $4 \mathrm{~m}$ x $40 \mathrm{~cm}$. Dasar kolam diberi tanah secukupnya dan diisi air sampai ketinggian $30 \mathrm{Cm}$. Inokulum azolla ditanam di kolam dengan kerapatan 200 g.m $\mathrm{m}^{-2}$ dan dipelihara selama 1-2 bulan sampai biomassa azolla yang diproduksi mencukupi kebutuhan percobaan.

Pot plastik berdiameter $40 \mathrm{~cm}$ diisi campuran tanah sawah sebanyak $7 \mathrm{~kg}$. Tanah dalam plot dilumpurkan dengan menambahkan air secukupnya kemudian diaduk-aduk sampai terbentuk lumpur. Biomassa azolla segar dengan takaran sesuai perlakuan dibenamkan ke dalam lumpur secara merata. Kemudian seluruh pot-pot percobaan diberi air sampai ketinggian $5 \mathrm{~cm}$ dan ditempatkan dalam rumah kaca. Bibit padi varietas Ciherang berumur 25-30 hari akan ditanamkan pada pot percobaan tersebut masing masing 2 bibit tanaman per pot.

Pengamatan paramater pertumbuhan dan hasil percobaan yang digunakan dalam penelitian ini meliputi: tinggi tanaman (cm); jumlah anakan; Jumlah anakan produtif (tanaman); berat kering tanaman (gram); berat kering gabah (gram); dan berat 1000 butir gabah (gram);

\section{HASIL DAN PEMBAHASAN}

\section{Pertumbuhan Tanaman}

Pemberian pupuk organik Azolla berpengaruh nyata terhadap peningkatan pertumbuhan tinggi, jumlah anakan dan berat kering brangkasan tanaman padi. Pemberian azolla sebanyak 400 g.pot ${ }^{-1}$ memberikan tinggi tanaman tertinggi (Tabel 1). Hasil ini sejalan dengan penelitian Rahmatika (2010) yang menununjukkan bahwa pemberian azolla yang dikombinasikan dengam urea memberikan pertumbuhan tinggi tanaman tertinggi.

Jumlah anakan pada umur umur 6 minggu tertinggi juga dicapai pada pemberian azolla sebanyak 400 g.pot ${ }^{-1}$ yaitu sebanyak 24 anakan (Tabel 1). Hasil ini berbeda dari hasil penelitian Arifin (1985) yang menunjukkan bahwa substitusi urea oleh azolla cenderung menurunkan jumlah anakan tanaman padi. Berat kering brangkasan tertinggi kembali dicapai pada pemberian azolla sebanyak 400 g. pot $^{-1}$ yaitu sebesar 62,93 gram (Tabel 1).

Tabel 1. Tinggi Tanaman, Jumlah Anakan Tanaman dan Berat Kering Brangkasan Padi Sawah dengan Pemberian Pupuk Organik Azolla.

\begin{tabular}{lccc}
\hline \multicolumn{1}{c}{ Perlakuan } & Tinggi Tanaman (cm) & Jumlah Anakan & $\begin{array}{c}\text { BeratKering } \\
\text { Brangkasan (gram) }\end{array}$ \\
\hline $\mathrm{M}_{0}$ (kontrol) & $70,47 \mathrm{a}$ & $19,67 \mathrm{a}$ & $52,33 \mathrm{a}$ \\
$\mathrm{M}_{1}$ = Azolla 100 g.pot ${ }^{-1}$ & $79,53 \mathrm{~b}$ & $16,67 \mathrm{a}$ & $48,05 \mathrm{a}$ \\
$\mathrm{M}_{2}$ = Azolla 200 g. pot $^{-1}$ & $81,73 \mathrm{~b}$ & $21,83 \mathrm{ab}$ & $53,75 \mathrm{a}$ \\
$\mathrm{M}_{3}$ = Azolla 300g. pot $^{-1}$ & $82,13 \mathrm{~b}$ & $22,33 \mathrm{ab}$ & $62,43 \mathrm{~b}$ \\
$\mathrm{M}_{4}=$ Azolla 400g. pot $^{-1}$ & $79,30 \mathrm{~b}$ & $24.00 \mathrm{~b}$ & $62,93 \mathrm{~b}$ \\
\hline
\end{tabular}

Keteragan: Nilai rata-rata yang diikuti dengan huruf yang sama dalam kolom tidak berbeda nyata menurut uji BNT pada taraf $5 \%$.

Pemberian pupuk organik azolla berpengaruh nyata terhadap jumlah anakan produktif, berat kering gabah dan berat 1000 butir gabah tanaman padi. Jumlah anakan produktif dan berat kering gabah maksimal dicapai pada pemberian azolla sebanyak 400 g. pot $^{-1}$ yaitu masing-masing 19,83 anakan dan 58,05 gram. Berat 1000 butir gabah tertinggi dip eroleh dengan pemberian azolla 
Iwan Gunawan: Kajian Peningkatan Peran Azolla Sebagai Pupuk Organik Kaya Nitrogen...

sebanyak 200 g. pot $^{-1}$. Persamaan regresi terpercaya diperoleh $Y=-2,028 x^{2}+19,51 x+9,430$ dengan nilai $\mathrm{R}^{2}=0,972$ (Gambar 1). Berdasarkan persamaan regresi di atas diperoleh nilsi berat kering gabah maksimal sebesar 56,35 gram dengan dosis pupuk organik azolla optimal sebanyak 48,102 ton.ha ${ }^{-1}$

Tabel 2. Jumlah Anakan Produktif, Berat Kering Gabah dan Berat 1000 Butir Gabah Padi Sawah dengan Pemberian Pupuk Organik Azolla.

\begin{tabular}{lccc}
\hline \multicolumn{1}{c}{ Perlakuan } & $\begin{array}{c}\text { Jumlah Anakan } \\
\text { Produktif }\end{array}$ & $\begin{array}{c}\text { Berat Kering Gabah } \\
\text { (gram) }\end{array}$ & $\begin{array}{c}\text { Berat 1000 Butir } \\
\text { Gabah (gram) }\end{array}$ \\
\hline $\mathrm{M}_{0}$ (kontrol) & $17,33 \mathrm{a}$ & $28,05 \mathrm{a}$ & $25,93 \mathrm{a}$ \\
$\mathrm{M}_{1}$ = Azolla 100 g.pot & 11 & $38,33 \mathrm{~b}$ & $25,26 \mathrm{a}$ \\
$\mathrm{M}_{2}$ = Azolla 200 g. pot $^{-1}$ & $16,67 \mathrm{a}$ & $48,99 \mathrm{c}$ & $29,78 \mathrm{~b}$ \\
$\mathrm{M}_{3}$ = Azolla 300g. pot & $17,67 \mathrm{a}$ & $54,93 \mathrm{~d}$ & $29,41 \mathrm{ab}$ \\
$\mathrm{M}_{4}$ = Azolla 400g. pot & $19,33 \mathrm{~b}$ & $58,05 \mathrm{e}$ & $26,27 \mathrm{a}$ \\
\hline
\end{tabular}

Keteragan: Nilai rata-rata yang diikuti dengan huruf yang sama dalam kolom tidak berbeda nyata menurut uji BNT pada taraf $5 \%$.

Gambar 1. Permukaan respon berat kering gabah tanaman padi sawah terhadap pemberian pupuk organik azolla

\section{KESIMPULAN}

Dari hasil penelitian dapat disimpulkan bahwa: (1) Pupuk organik azolla meningkatkan pertumbuhan dan hasil tanaman padi sawah,dan (2) Hasil gabah kering maksimal 56,35 gram per tanaman dengan dosis pupuk organik azolla optimal sebanyak 48,102 ton.ha ${ }^{-1}$. Disarankan penelitian lanjutan untuk mempelajari pengaruh bentuk pupuk organik berbahan baku Azolla terhadap pertumbuhan dan hasil padi sawah.

\section{DAFTAR PUSTAKA}

Arifin, Z. 1985. Keefisienan nitrogen dari Azolla pinnata dan Urea terhadap pertumbuhan dan produksi tanaman padi (Oryza sativa) varietas IR-36. Jurusan Tanah, Fakultas Pertanian. Institute Pertanian Bogor. Bogor 1985. 
Jurnal Penelitian Pertanian Terapan

Gunawan, I. dan R. Kartina, 2012. Substitusi kebutuhan nitrogen padi sawah oleh tumbuhan air azolla (Azolla pinnata). Jurnal Penelitian Pertanian Terapan. Volume 12, No. 3, September 2012

Haryanto. 2010. Pemanfaatan azolla sebagai sumber nitrogen terbarukan dalam sistem budidaya pad isawah yang ramah lingkungan. Laporantahapakhir. Laporan kemajuan program insentif. Pusat Aplikasi Teknologi Isotop dan Radiasi. BATAN. 2010

Hendrarti, E., D.Sopandie,K. Idris,danE.L. Sisworo.1998. Pengaruh lapisan azolla terhadap pertumbuhan, produksi dan efisiensi penggunaan pupuk urea bertanda $15 \mathrm{~N}$ pada padi sawah. Pertemuan Ilmiah Penelitian dan Pengembangan Aplikasi Isotop dan Radiasi, Jakarta (Indonesia), 18-19 Feb 1998. BATAN, Jakarta .

Kaimuddin, B.,Ibrahim dan L. Tangko. 2008. Budidaya padi sawah irigasi dengan aplikasi azolla dan ikan nila. Journal Agrivigor 7(3):242-253. Mei-Agustus 2008.

Kusumo, D. 2008. Beberapa hasil penelitian tentang azolla. http://kolamazolla.blogspot.com/2009/10/penelitian-azolla-di-faperta-ugm.html

Rahmatika, W. 2010. Pertumbuhan tanaman padi (Oryza sativa L.) akibat pengaruh persentase N (Azolla dan urea). Primordia Volume 6, Nomor 2, Juli 2010.

Rasjid, H.,E.L.Sisworo.,Y. Wemay,,W.H. Sisworo. 2000. Efisiensi N-urea pada padisawah yang diaplikasi dengan azolla. Pertemuan Ilmiah Penelitian dan Pengembangan Teknologi Isotopdan Radiasi, Jakarta (Indonesia), 23-24 Feb 2000. PuslitbangTeknologiIsotopdanRadiasi, Jakarta (Indonesia). [Proceedings of scientific meeting on research and development of isotope and radiation technology], Suhadi, F.Darwis, D.Hilmy, N.Indris, K.Ismachin, M.Leswara, N.D.Manurung, S.Sisworo, E.L.Sumatra, M.Sutrisno, S.Utama, M.WandowodanH.Winarno (ed.) Jakarta (Indonesia) .PuslitbangTeknologiIsotopdanRadiasi. 2000.- ISBN 979-95709-5-6. p. 139-143. 